\title{
Containing Ebola virus infection in West Africa
}

J Kucharski (adam.kucharski@lshtm.ac.uk) ${ }^{1}$, P Piot ${ }^{1}$

1. London School of Hygiene \& Tropical Medicine, London, United Kingdom

Citation style for this article:

Kucharski AJ, Piot P. Containing Ebola virus infection in West Africa. Euro Surveill. 2014;19(36):pii=20899. Available online: http://www.eurosurveillance.org/ ViewArticle.aspx?Articleld $=20899$

Article submitted on 08 September 2014 / published on 11 September 2014

Ebola virus disease (EVD) is leaving a mark deeper and wider than ever before. The current outbreak now spans five countries in West Africa - Guinea, Liberia, Nigeria, Senegal and Sierra Leone - with over 4,200 cases and 2,200 deaths reported to the World Health Organization (WHO) as of 6 September 2014 (Figure 1) [1]. Unfortunately, with many cases either not reported or yet to show symptoms, the true number of infections is likely to be considerably higher. The first countries affected were among the world's poorest, areas where long periods of civil wars have battered health services and eroded public trust. As a result, the outbreak has spread to other countries, and continues to expand. What began as a local problem has turned into an international crisis.

\section{Challenges for control in Africa}

Past Ebola outbreaks have never risen beyond a few hundred reported cases, and even these events have been comparatively rare. When EVD spills over from its animal host into human populations, it typically generates dozens rather than hundreds of infections [2].

\section{FIGURE}

Cumulative number of Ebola virus disease cases and deaths in West Africa, April to 6 September 2014

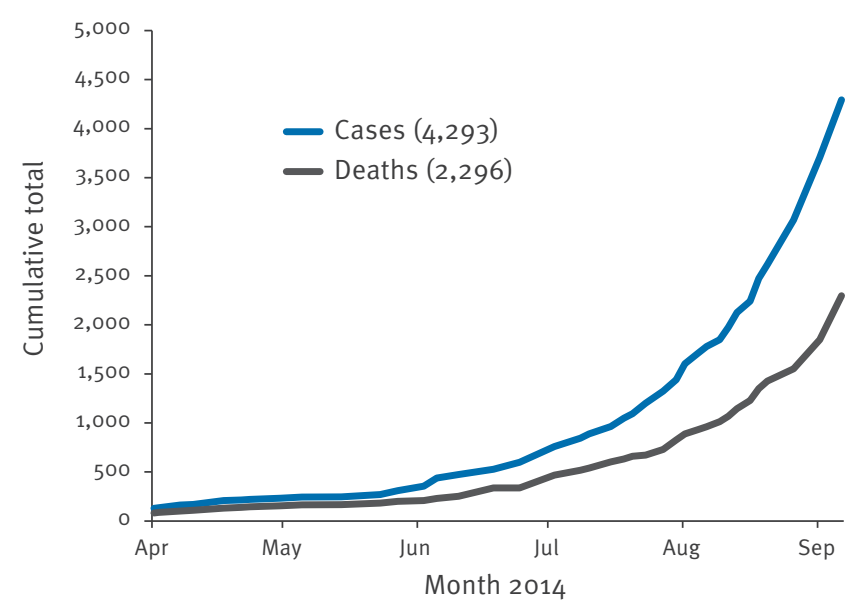

Source: World Health Organization [1]
Chance events in the early stages of an outbreak can have a large impact on its final size. Infected individuals' movement patterns, social interactions, beliefs about disease causation and trust in authorities can all influence the extent of transmission, and hence the scale of control measures required to stop the infection.

In theory, Ebola is easily containable. It has a long incubation period - around a week on average - and cases are typically infectious only after displaying symptoms $[3,4]$. This means that isolation of symptomatic patients, contact tracing and follow-up surveillance of all contacts should be sufficient to stop transmission. Contrast this with pandemic influenza, which has a much shorter incubation period and can generate numerous cases who may be asymptomatic yet infectious [5]. For isolation to be effective during an Ebola outbreak, however, there must be rapid identification of cases and follow-up of contacts. Several factors can hinder this. In settings with limited testing facilities, cases that are not tested can be misdiagnosed. Not all EVD patients display distinctive hemorrhagic symptoms: the 1994 Ebola outbreak in Gabon was originally attributed to yellow fever [6], and early cases in the 1995 Kikwit outbreak were mistaken for dysentery and typhoid fever [7].

The exponential growth in case numbers during an outbreak also makes resource-intensive activities like contact tracing and surveillance increasingly difficult. Recent studies, including the one by Nishiura et al. in this issue, suggest that the reproduction number of Ebola (the average number of secondary cases generated by a typical case) is between 1.5-2 in some countries $[8,9]$. Based on the durations of incubation and infectiousness of EVD [3], it is plausible that the number of cases could therefore double every fortnight if the situation does not change. There are currently hundreds of new EVD cases reported each week; with the number of infections increasing exponentially, it could soon be thousands. Following up contacts and monitoring them for symptoms has already become unfeasible in areas where health authorities are stretched to the limit. 
Disease control efforts in West Africa have been further hampered by cases not attending healthcare facilities, and instead remaining in the community. Fear and mistrust of health authorities has contributed to this problem, but increasingly it is also because isolation centres have reached capacity. As well as creating potential for further transmission, large numbers of untreated - and therefore unreported - cases make it difficult to measure the true spread of infection, and hence to plan and allocate resources. Even if patients are isolated, however, and their close contacts successfully traced, efforts can be undermined by unpredictable behavior. This was exemplified by the outbreak reported last week in Port Harcourt, Nigeria, which started after a contact of the index case in Lagos broke quarantine and left the capital [10].

Fear and mistrust are not unique to the current Ebola outbreak. During the 2000-1 outbreak in Uganda, health authorities faced similar challenges, including public protests, lack of co-operation from followedup contacts, and shortages of staff willing to work in Ebola isolation units [11]. To control the infection, authorities needed to provide leadership and build trust. Interventions included education in various settings: in the community, educators strived to instill confidence, explaining how to avoid infection and recognise symptoms, while in hospitals, healthcare workers were provided with additional training, support and protection [12].

Education can also help address cultural practices that fuel outbreaks. The initial chain of Ebola virus transmission in Guinea in early 2014 included two funerals [13], and in May, another funeral introduced the epidemic to Sierra Leone [14]. Again, this is not just a feature of the present outbreak in West Africa. Funeral practices contributed to previous outbreaks in Central Africa too, but in many instances, it was possible to change people's behaviour. With support from health educators, communities altered the way burials were conducted, reducing transmission $[12,15]$.

\section{Need for an international response}

Introducing control measures requires substantial resources, and there is a limit to what a local response can achieve alone. Yet as the current outbreak has grown, neighboring countries have closed borders and introduced travel restrictions. Similar actions were taken during past outbreaks, such as the one in Uganda in 2000-1 [16]. Such restrictions can hinder control efforts, making it harder to bring in personnel and resources.

Ebola cannot be ignored in the hope it will burn itself out. It is true that outbreaks of acute infections will generally decline once a large number people have been infected, because there are no longer enough susceptible individuals to sustain transmission. But if Ebola indeed has a reproduction number of 2 in some locations as described by Nishiura et al. [8], the susceptible pool - which likely includes most individuals - would have to shrink by at least half before the outbreak declined of its own accord [17]. Given the vast populations in affected areas and the disease's high fatality rate, this is clearly not an acceptable scenario.

Stopping transmission will instead require stronger control measures. On 28 August, the WHO issued a road map to provide a plan for the Ebola response [18]. It had three main objectives: (i) to achieve full coverage of control measures in countries with widespread transmission; (ii) to introduce emergency interventions in countries with an index case or small outbreak; and (iii) to strengthen Ebola preparedness in other countries, especially those connected to affected areas.

The scale of the current outbreak means an international response is needed. The threat to Europe and other continents remains low - in countries with strong health systems, an imported case should be straightforward to contain [19] - but without containment the devastation in West Africa will continue. Much of the damage is now coming from knock-on effects on basic healthcare. Not just EVD patients are affected by the outbreak; in cities like the Liberian capital Monrovia, the presence of the infection has led to the closure of most health facilities. As a result, untreated injuries and illnesses are leading to further loss of life.

In collaboration with affected countries, the international community must commit the resources required to control the outbreak. A week ago, Médecins Sans Frontières announced an urgent need for expertise and equipment [20]. As well as financial support, affected countries require experienced healthcare workers and specialists in biological disasters. The response must also include additional protective clothing and isolation units, and diagnostic tools and laboratory testing facilities. Health authorities will need food for those in quarantine too, plus vehicles to transport patients and trace their contacts, and air support to move resources between affected areas.

The scientific community can also support control efforts. Mathematical modelers can help quantify transmission in different areas, and provide short-term forecasts. Researchers are also working on potential drugs and vaccines. On 4 and 5 September 2014, WHO held a meeting to discuss what treatments are currently in development [21]. Testing of these experimental therapies and vaccines will soon start and must be fast-tracked to establish their safety and efficacy.

The effort required to control EVD will inevitably vary by country. In some locations, it has been suggested that the reproduction number could already be near 1 ; in others it could still be as high as 2 [8]. As pointed out above, the size of the transmission and the reproduction number will be influenced by multiple factors, including the level of public trust in authorities 
and health services, as well as behaviours and beliefs shaped by social and cultural traditions. Transmission is also likely to be setting-specific. The reproduction number is an average value: some individuals and interactions will contribute more to transmission than others. The infection will be easier to control if it is possible to identify and target these crucial links in the transmission chain.

Over the past 38 years, there have been more than twenty Ebola outbreaks, and all of them have been successfully contained. Many of the issues currently facing West Africa - from lack of trust in health authorities to poor infection control - have surfaced before, and have been overcome. However, the current outbreak is unprecedented both in size and scale. It will require a response to match.

\section{Conflict of interest}

None declared.

\section{References}

1. World Health Organization (WHO). Ebola virus disease outbreak $\neg$ west Africa. 4 September 2014. Geneva: WHO, 2014. Available from: http://www.who.int/csr/ don/2014_09_04_ebola/en/

2. Centers for Disease Control and Prevention (CDC). Outbreaks Chronology: Ebola Hemorrhagic Fever. Updated 6 September 2014. Atlanta: CDC, 2014. Available from: http://www.cdc.gov/ vhf/ebola/resources/outbreak-table.html

3. Breman J, Piot P, Johnson K, White M, Mbuyi M, Sureau P, et al. The epidemiology of Ebola hemorrhagic fever in Zaire, 1976. Ebola virus haemorrhagic fever. Pattyn, SR ed. Amsterdam: Elsevier/North Holland Biomedical Press; 1978. p. 85-97.

4. Dowell SF, Mukunu R, Ksiazek TG, Khan AS, Rollin PE, Peters CJ for the Commission de Lutte contre les Epidémies à Kikwit. Transmission of Ebola hemorrhagic fever: a study of risk factors in family members, Kikwit, Democratic Republic of the Congo, 1995. J Infect Dis. 1999; 179 Suppl 1:S87-91. http:// dx.doi.org/10.1086/514284

5. Fraser C, Riley S, Anderson RM, Ferguson NM. Factors that make an infectious disease outbreak controllable. Proc Natl Acad Sci U S A. 2004;101(16):6146-51. http://dx.doi. org/10.1073/pnas.0307506101

6. Amblard J, Obiang P, Edzang S, Prehaud C, Bouloy M, Guenno BL. Identification of the Ebola virus in Gabon in 1994. Lancet 1997;349(9046):181-2. http://dx.doi.org/10.1016/ So140-6736(05)60984-1

7. Khan AS, Tshioko FK, Heymann DL, Le Guenno B, Nabeth P, Kerstiëns B, et al. The reemergence of Ebola hemorrhagic fever, Democratic Republic of the Congo, 1995. I Infect Dis. 1999;179 Suppl:S76-86. http://dx.doi.org/10.1086/514306

8. Nishiura H, Chowell G. Early transmission dynamics of Ebola virus disease (EVD), West Africa, March to August 2014. Euro Surveill. 2014;19(36): pii=20894.

9. Gomes MFC, Pastore y Piontti A, Rossi L, Chao D, Longini I, Halloran ME, et al. Assessing the International Spreading Risk Associated with the 2014 West African Ebola Outbreak. PLOS Currents Outbreaks. 2014 Sep 2. Edition 1. Available from: http://currents.plos.org/outbreaks/article/assessing-theinternational-spreading-risk-associated-with-the-2014-westafrican-ebola-outbreak/

10. World Health Organization (WHO). Ebola situation in Port Harcourt, Nigeria. Situation assessment 3 Sep 2014. Geneva: WHO, 2014. Available from: http://who.int/mediacentre/news/ ebola/3-september-2014/en/

11. Borchert M, Mutyaba I, Van Kerkhove MD, Lutwama J, Luwaga $\mathrm{H}$, Bisoborwa $\mathrm{G}$, et al. Ebola haemorrhagic fever outbreak in Masindi district, Uganda: outbreak description and lessons learned. BMC Infect Dis. 2011;11:357. http://dx.doi. org/10.1186/1471-2334-11-357
12. Lamunu M, Lutwama J), Kamugisha, J, Opio A, Nambooze J, Ndayimirije $\mathrm{N}$, et al. Containing a haemorrhagic fever epidemic: the Ebola experience in Uganda (October 2000-January 2001). Int J Infect Dis. 2004;8:27-37. http://dx.doi.org/10.1016/j. ijid.2003.04.001

13. Baize S, Pannetier D, Oestereich L, Rieger T, Koivogui L, Magassouba N, et al. Emergence of Zaire Ebola virus disease in Guinea - Preliminary report. N Engl J Med. 2014. http://dx.doi. org/10.1056/NEJMoa1404505

14. Gire SK, Goba A, Andersen KG, Sealfon RS, Park DJ, Kanneh L, et al. Genomic surveillance elucidates Ebola virus origin and transmission during the 2014 outbreak. Science 2014;1259657.

15. Hewlett BL, Hewlett BS. Providing care and facing death: nursing during Ebola outbreaks in central Africa. J Transcult Nurs. 2005;16(4):289-97. http://dx.doi. org/10.1177/1043659605278935

16. Okware SI, Omaswa FG, Zaramba S, Opio A, Lutwama JJ, Kamugisha J, et al. An outbreak of Ebola in Uganda. Trop Med Int Health. 2002;7(12):1068-75. http://dx.doi. org/10.1046/j.1365-3156.2002.00944.X

17. Keeling M, Rohani P. Modeling Infectious Diseases in Humans and Animals. New Jersey: Princeton University Press; 2007.

18. World Health Organization (WHO). Ebola response roadmap. Geneva: WHO, 2014. Available from: http://www.who.int/csr/ resources/publications/ebola/response-roadmap/en/

19. European Centre for Disease Prevention and Control (ECDC). Outbreak of Ebola virus disease in West Africa. Fourth update, 3 Sep 2014. Stockholm: ECDC; 2014. Available from: http:// www.ecdc.europa.eu/en/publications/Publications/Ebolavirus-disease-west-africa-risk-assessment-27-08-2014.pdf

20. Médecins Sans Frontières (MSF). United Nations Special Briefing on Ebola. 2 Sep 2014. New York: MSF; 2014. Available from: http://www.doctorswithoutborders.org/news-stories/ speechopen-letter/united-nations-special-briefing-ebola

21. World Health Organization (WHO). Statement on the WHO Consultation on potential Ebola therapies and vaccines. 5 Sep 2014. Geneva: WHO, 2014. Available from: http://who.int/mediacentre/news/statements/2014/ ebola-therapies-consultation/en/ 